\title{
SCHEDULING OF JOB RESOURCES IN MULTIUNIT PROJECTS WITH THE USE OF TIME / COST CRITERIA
}

\section{PODOLSKI ${ }^{1}$}

\begin{abstract}
This paper presents a model of scheduling of multiunit construction project based on an NP-hard permutation flow shop problem, in which the considered criterion is the sum of the costs of the works' execution of the project considering the time of the project as a constraint. It is also assumed that each job in the units constituting the project may be realized in up to three different ways with specific time and cost of execution. The optimization task relies on solving the problem with two different decision variables: the order of execution of units (permutation) and a set of ways to carry out the works in units. The task presented in the paper is performed with the use of a created algorithm which searches the space of solutions in which metaheuristic simulated annealing algorithm is used. The paper presents a calculation example showing the applicability of the model in the optimization of sub-contractors' work in the construction project.
\end{abstract}

Keywords: construction projects scheduling, simulated annealing, flow - shop, optimization, contractor selection

\section{INTRODUCTION}

In reference to the possibility of planning, construction projects can be divided into two basic types: "complex of operations" projects and those that can be organized in flow organization system [8]. The above distinction is to be understood as follows: each building project can be considered as a complex operation but only some of them can be organized in flow organization system. Currently, in the scheduling of "complex of operations" projects, in practice, most frequently used network methods are: deterministic in nature - CPM or PERT of non-deterministic character.

In the group of scheduling models considered for projects like "complex of operations" problems of optimal allocation of resources seem to be the most important.

\footnotetext{
1 PhD., Eng., Wrocław University of Technology, Faculty of Civil Engineering, Wyb. Wyspiańskiego 27,
} 50-370 Wrocław, Poland, e-mail: michal.podolski@pwr.edu.pl 
Among them there the following optimization problems can be distinguished: the times of work execution and durations of activities should be determined in order to:

- minimize the duration of the project with the total cost given or

- minimize the total cost of the project, which is not to exceed final deadline for its implementation.

This problem belongs to a group of a single objective optimization problem and until now it has been one of the most frequently considered in the context of operational research (in foreign literature it is described in terms of "time-cost trade-off" - in short - TCT). The problem of resource allocation (in case of TCT - costs) for a discrete time/cost dependency is NP-hard. To solve this problem in construction projects the most frequently used are approximate metaheuristic algorithms, with different degrees of accuracy in obtaining results, such as: genetic [3, 10], simulated annealing [1], ant colony [14, 19] or hybrid algorithm [18].

In the second group there are projects realized in a flow organization system $[6,11,12]$. They rely on the implementation of a set of units or a single object partitioned into work zones. Such projects embrace for instance: multi-storey buildings, single-family housing developments or group of buildings, linear objects (highways, road networks, and pipelines).

The most commonly considered scheduling optimization criterion for projects implemented in this system is the duration of the entire project taking into account the decision variable -ability to change the sequence of execution of units $[2,12,16]$. There are few works in which the criterion considered for this system is the cost of the project which is understood as the sum of the cost of the works in the project and it takes into account the possibility of changing the order of execution of units $[15,17]$.

This paper proposes a model of flow organization system, in which the cost of works execution in the project is included, which will lead to solving discrete optimization problems with the time/cost dependency, similar to the one described in the above TCT problem.

\section{DESCRIPTION OF THE CONSIDERED MULTIUNIT PROJECT}

The considered in the paper model assumes the acceptance of deterministic situations where the technical, technological and organizational conditions are known and accurate with an available bill of quantities. At any given time resources (working groups) are available to perform the work with the established performance and quality. There are no significant disruptions in the performance of work by the working groups. Relationships between jobs are expressed in a constant, for each unit, 
sequence (order). It is a dependency encountered for buildings with a simple work technology such as in case of single-family houses. For these units works will be performed in a sequence, e.g. earthworks, foundations, walls with slabs, rafter framings, etc. In the presented model of a multiunit project, the partial overlap in the sequence of the works or the presence of the intervals between them is allowed.

The above system can be found in performance practice, where, for example, the early commencement of works made before the end of the works of the previous type is allowed. The system also allowed for additional time required for the movement of the working groups between units, depending on the nature of the working group and the sequencing of units. This is an important parameter for the projects in which the undertaken construction works in are at a distance from each other [4].

A separate problem is the choice of resources to be implemented in the project. It is assumed that any type of work can be done in a maximum three ways considering the duration and cost of the work. Such a situation can be seen when the project developer has access to offers made by subcontractors for certain types of work. They will contain the declared duration and cost of the specific work throughout the whole project (i.e. on all units). The described resource selection issue comes down to the choice of a method with which the project will be performed.

In connection with the above project description, in the presented model, optimization problem can be distinguished in which there are two, separate decision variables. The first is the allocation of units, which is represented by a permutation of length equal to the number of units. The second is a matrix of numbers representing the methods of works implementation (1 to 3 ) with dimensions equal to the number of works and the number of units in the project.

The optimization problem in the presented model will be a single objective optimization task, which will rely on minimizing of the cost of the entire project considering set limitation on the date of its execution. The above described optimization problem was not yet investigated in the literature on scheduling of construction projects. The paper proposes the solution using new algorithm created by the author. In steps of algorithm the simulated annealing algorithm will be applied.

\section{OPTIMIZATION MODEL OF MULTIUNIT PROJECT}

In the considered flow organization model there are assumptions from permutation flow shop problem used with the criterion of time of execution of all tasks (problem FP ||$C_{\text {max }}$ ), which is studied in the theory of scheduling. On the basis of this problem a considered model has been 
formulated which uses additional parameters and constraints. The model assumes that one type of work is performed by one working group selected from the team of working groups (group of subcontractors). The optimization model of the above described problem is as follows:

\section{Parameters:}

- The project consists of a set of building units $Z=\left\{Z_{1}, Z_{2}, Z_{3}, \ldots, Z_{j}, \ldots, Z_{n}\right\}$.

- In order to carry out the project works the working groups perform one job of one type which constitute the set $B=\left\{B_{1}, B_{2}, B_{3}, \ldots, B_{k}, \ldots, B_{m}\right\}$.

- In each team of working groups $B_{k} \in B$ there are three working groups representing various subcontractors (with different capacities and configurations): $B_{k}=\left\{B_{k 1}, B_{k i}, B_{k 3}\right\}$, where $i=1 \ldots 3$.

- Each object $Z_{j} \in Z$ requires implementation of $m$ works which form the set $O_{j}=\left\{O_{j 1}, O_{j 2}, O_{j 3}, \ldots\right.$, $\left.O_{j k}, \ldots, O_{j m}\right\}$.

- It is assumed that the work $O_{j k} \in O_{j}$ can be done by the working group $B_{k i} \subset B_{k}$. The duration of the work $O_{j k}$ performed by the group is $p_{j k i}>0$. The set of possible durations of works from the set $O_{j}$ performed by the working group $B_{k i}$ defines vector $p_{i}=\left[p_{j 1}, p_{j 2}, p_{j 3}, \ldots, p_{j k}, \ldots, p_{j m}\right]$, where $p_{j k}=\left[p_{j k 1}, p_{j k i}, p_{j k 3}\right]$. Duration of works $p_{j k i}$ are determined on the basis of workload and workgroup size (number of workers) $B_{k i}$ performing the work $O_{j k}$.

- Similarly as the above, it is assumed that the work $O_{j k} \in O_{j}$ can be implemented by the working group $B_{k i} \subset B_{k}$. The cost of realization of the work $O_{j k}$ by the working group $B_{k i}$ defines a variable $u_{j k i} \geq 0$. The set of possible costs of works $u_{j}$ from the set $O_{j}$ is defined by the vector $u_{j}=\left[u_{j 1}, u_{j 2}, u_{j 3}, \ldots, u_{j k}, \ldots, u_{j m}\right]$, where $u_{j k}=\left[u_{j k 1}, u_{j k i}, u_{j k 3}\right]$. The cost of the work $u_{j k i}$ is determined by the calculation of the cost of execution of the work $O_{j k}$ by the working group $B_{k i}$ located in the resources of the contractor. It may also be the cost offer of the execution of the work $O_{j k}$ made by the subcontractor represented by the working group $B_{k i}$. It is assumed that the time of execution of works $p_{j k i}$ is convex, decreasing cost functions $u_{j k i}$.

- There is the possibility of technological gaps between the works and the simultaneous operation of multiple working groups in the units assumed. Durations of intervals between a given work and the next work $\left(s_{j k}^{F}>0\right)$ or the length of the simultaneous duration of a given work and the next work $\left(s_{j k}^{F}<0\right)$ in the unit for a set of works $O_{j}$ are given in vector $s_{j}^{F}=\left[s_{j 1}^{F}, s_{j 2}^{F}, s_{j 3}^{F}, \ldots\right.$, $s_{j k}^{F}, \ldots, s_{j m}^{F}$. They are equivalent to couplings between working fronts, which are used in [11]. These times should be understood as the minimum constraints and can take on any value. In the further work there will be called couplings between units. 
- Additional time required for the movement of the working groups between units, depending on the type of the working group and the sequencing of units is defined by the $m$ matrices $S_{k}^{S}=\left[S^{S}{ }_{g h}\right]$ of size $n \times n$, where $g \in[1 . . n], h \in[1 . . n], k \in[1 . . m]$.

\section{Constraints:}

- The order of execution of the works resulting from work technology is assumed such that: $O_{j, k-1} \prec O_{j, k} \prec O_{j, k+1}$.

- It is assumed that each working group from the team $B_{k}$ can perform only one job at a time.

- It is assumed that the work $O_{j k} \in O_{j}$ is performed continuously by the working group $B_{k i} \subset B_{k}$ in time $p_{j k i}>0$.

- It is assumed that the constraint of time of completion of all the works in units takes on the value $\hat{C}: C_{\max } \leq \hat{C}$, where $C_{\max }$ is the duration time of the entire project.

Decision variables are the order $\pi$ of execution of units, which, for each of the working group, is the same and takes the form of a permutation $\pi=(\pi(1), \pi(2), \pi(3), \ldots, \pi(j), \ldots, \pi(n))$ and a set of numbers of ways of work execution (from $i=1$ to $i=3$ ) in all units of the project is $R=\left(R_{1}, R_{2}, R_{3}\right.$, $\left.\ldots, R_{j}, \ldots, R_{n}\right), R \in \Re$, where $R_{j}=\left(R_{j 1}, R_{j 2}, R_{j 3}, \ldots, R_{j k}, \ldots, R_{j m}\right), R_{j k}$-the number of ways of realization (from $i=1$ to $i=3$ ) of the work $k$ in object $j, \Re$ - the set of all possible ways to carry out the works in the project.

The value of the number $i$ of the way of realization $R_{j k}$ enables allocation of the working group $B_{k i}$ from the team $B_{k}$ to the work $k$ in the object $j$.

The form of the decision variable $R$ uniquely identifies the allocation of working groups to realization of works in the units. Therefore, using the decision variable $R$ there establishes not only the durations of individual works carried out in the units but also their cost.

After the adoption of the decision variable $R$ the durations of works $p_{j}$ from the set $O_{j}$ is as follows: $p_{j}=\left\{p_{j 1}, p_{j 2}, p_{j 3}, \ldots, p_{j k}, \ldots, p_{j m}\right\}$, where $p_{j k}$ is the duration of the execution of the work $k$ in the object $j$. Similarly, consequently with the adoption of the decision variable $R$ the set of costs $u_{j}$ of works from the set $O_{j}$ is as follows: $u_{j}=\left\{u_{j 1}, u_{j 2}, u_{j 3}, \ldots, u_{j k}, \ldots, u_{j m}\right\}$, where $u_{j k}$ is the cost of implementing work $k$ in object $j$. 
Objective function will be the cost of the project at the assumed constraint of the date of its completion.

More specifically, the minimum cost of the entire project is searched for (which is the sum of the cost of individual works) by the permutation $\pi^{*} \in \Pi$ and for the decision variable $R^{*} \in R$, for which:

$$
U\left(\pi^{*}, R^{*}\right)=\min _{R \in \Re, \pi \in \Pi} U(\pi, R), \quad \text { where } U(\pi, R)=\sum_{j=1}^{n} \sum_{k=1}^{m} u_{j k},
$$

$\Pi$ - the set of all possible permutations of a given project, $n$ - the number of all working units, $m-$ the number of works required for the realization of each of the object, assuming that the deadline for completion of the entire project $C_{\max }\left(\pi^{*}, R^{*}\right)$ does not exceed the indicative time limit imposed by the investor $\hat{C}: C_{\max }\left(\pi^{*}, R^{*}\right) \leq \hat{C}$.

The deadlines for the individual works for the decision variables $\pi$ and $R$ can be determined from the recursive formula:

$$
C_{k, \pi(j)}=\max \left\{C_{k, \pi(j-1)}+s_{k, \pi(j-1) \pi(j)}, C_{k-1, \pi(j)}+s_{k-1, \pi(j)}^{F}\right\}+p_{k, \pi(j)},
$$

where: $j=1, \ldots, n, k=1, \ldots, m, \pi(0)=0, C_{k, 0}=0, C_{0, j}=0$.

The duration of the entire project $C_{\max }$ (time execution of all works in the units) for $\pi^{*} \in \Pi$ and for the decision variable $R^{*} \in \Re$ is:

$$
C_{\max }\left(\pi^{*}, R^{*}\right)=C_{m, \pi^{*}(n)}
$$

The deadlines for the performance of individual works and their cost can be found in time $O(\mathrm{~nm})$. The number of possible solutions to the presented model is $n ! l^{m n}$, where $l$ - is the number of possible ways to implement $m$ works in $n$ units of the project (with assumed $l=3$ ). 


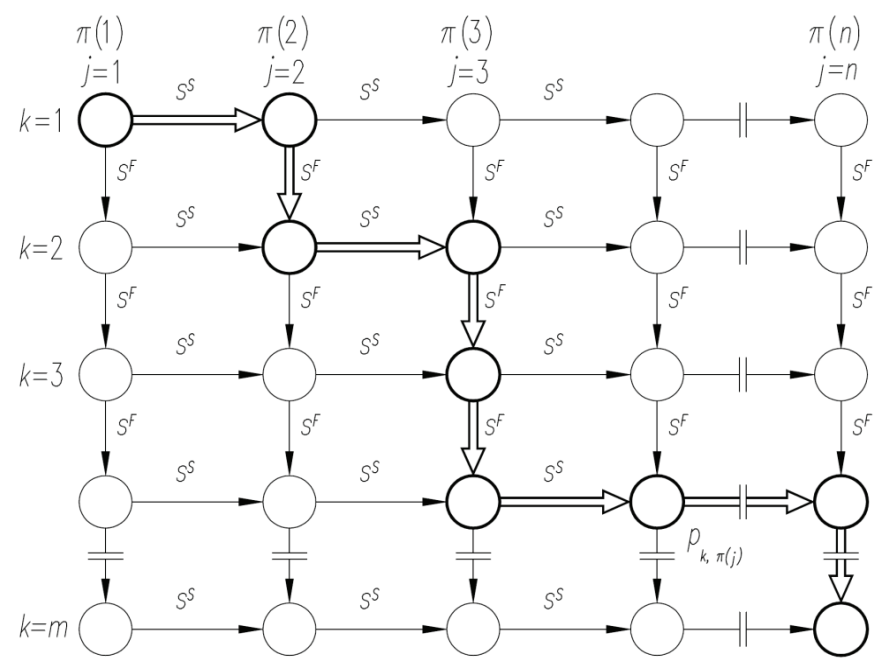

Fig. 1. The graph for the described model of the project with the marked critical path

The above presented model is NP-hard optimization problem. To solve the optimization task there is an individual algorithm proposed. This algorithm will use approximate metaheuristic simulated annealing algorithm.

\section{COMPUTATION EXAMPLE}

The contractor, on behalf of the investor, has to realize a project which relies on the construction of $n=7$ residential buildings (units). Each of them requires execution of $m=9$ works carried out in a fixed order. The project will be implemented in full by the subcontractors. For each type of work the contractor has received three bids from the subcontractors for the construction of individual buildings which are shown in Table 1. Each of the tender offers includes the execution time of a given type of work in particular units expressed in working days and the cost of their implementation expressed in zlotys. Between the works realized in the technological order there are couplings between units that have been established on the basis of existing technological constraints which are shown in Table 2. The data concerning the time required due to the movement of the working groups between units (depending on the nature of the working group and the sequencing of units) are stored in the form of $m=9$ matrix $S_{k}{ }_{k}: S_{1}{ }_{1}=S_{2}{ }_{2}=s_{g h}=2, S_{3}=S_{4}{ }_{4}=S_{7}{ }_{7}=s_{g h}=1, S_{5}{ }_{5}=$ $S_{6}{ }_{6}=S_{8}^{S}=S_{9}^{S}=S_{g h}=0$. 
Table 1. Offers of the works execution in $n=7$ buildings for $m=9$ works submitted by subcontractors including the duration of the works and their cost

\begin{tabular}{|c|c|c|c|c|c|c|c|c|}
\hline \multirow{2}{*}{\multicolumn{2}{|c|}{ CONTRACTORS (NUMBER/OFFER) }} & \multicolumn{7}{|c|}{ UNITS $j=$} \\
\hline & & 1 & 2 & \multirow[t]{2}{*}{3} & \multirow[t]{2}{*}{4} & \multirow[t]{2}{*}{5} & \multirow[t]{2}{*}{6} & \multirow[t]{2}{*}{7} \\
\hline \multicolumn{4}{|c|}{ Earthworks $(k=1)$} & & & & & \\
\hline \multirow{2}{*}{1} & Execution time [working days] & 12 & 18 & 11 & 15 & 18 & 13 & 19 \\
\hline & Execution cost [in thous. zl] & 5,50 & 8,25 & 5,04 & 6,88 & 8,25 & 5,96 & 8,71 \\
\hline \multirow{2}{*}{2} & Execution time [working days] & 10 & 22 & 12 & 11 & 19 & 14 & 17 \\
\hline & Execution cost [in thous. zl] & 6,60 & 6,75 & 4,62 & 9,38 & 7,82 & 5,53 & 9,73 \\
\hline \multirow{2}{*}{3} & Execution time [working days] & 11 & 14 & 11 & 11 & 15 & 11 & 15 \\
\hline & Execution cost [in thous. zl] & 3,88 & 4,37 & 4,67 & 4,80 & 4,90 & 3,67 & 6,41 \\
\hline \multicolumn{9}{|c|}{ Foundations $(k=2)$} \\
\hline \multirow{2}{*}{1} & Execution time [working days] & 18 & 17 & 10 & 6 & 16 & 29 & 13 \\
\hline & Execution cost [in thous. zl] & 24,00 & 22,67 & 13,33 & 8,00 & 21,33 & 38,67 & 17,33 \\
\hline \multirow{2}{*}{2} & Execution time [working days] & 14 & 12 & 8 & 8 & 18 & 36 & 16 \\
\hline & Execution cost [in thous. zl] & 30,86 & 32,11 & 16,67 & 6,00 & 18,96 & 31,15 & 14,08 \\
\hline \multirow{2}{*}{3} & Execution time [working days] & 16 & 22 & 11 & 7 & 17 & 27 & 11 \\
\hline & Execution cost [in thous. zl] & 27,00 & 17,52 & 12,12 & 6,86 & 20,08 & 41,53 & 20,48 \\
\hline \multicolumn{9}{|c|}{ Walls, slabs $(k=3)$} \\
\hline \multirow{2}{*}{1} & Execution time [working days] & 40 & 21 & 35 & 34 & 12 & 57 & 19 \\
\hline & Execution cost [in thous. zl] & 65,50 & 34,39 & 57,31 & 55,68 & 19,65 & 93,34 & 31,11 \\
\hline \multirow{2}{*}{2} & Execution time [working days] & 28 & 21 & 44 & 35 & 12 & 68 & 17 \\
\hline & Execution cost [in thous. zl] & 93,57 & 34,39 & 45,59 & 54,08 & 19,65 & 78,24 & 34,77 \\
\hline \multirow{2}{*}{3} & Execution time [working days] & 50 & 16 & 36 & 27 & 13 & 43 & 16 \\
\hline & Execution cost [in thous. zl] & 52,40 & 45,13 & 55,72 & 70,11 & 18,14 & 123,73 & 36,95 \\
\hline \multicolumn{9}{|c|}{ Rafter framings, roofing $(k=4)$} \\
\hline \multirow{2}{*}{1} & Execution time [working days] & 13 & 10 & 14 & 8 & 8 & 12 & 17 \\
\hline & Execution cost [in thous. zl] & 35,50 & 27,31 & 38,23 & 21,85 & 21,85 & 32,77 & 46,42 \\
\hline \multirow{2}{*}{2} & Execution time [working days] & 10 & 12 & 13 & 6 & 6 & 12 & 15 \\
\hline & Execution cost [in thous. zl] & 46,15 & 22,76 & 41,17 & 29,13 & 29,13 & 32,77 & 52,61 \\
\hline \multirow{2}{*}{3} & Execution time [working days] & 13 & 10 & 18 & 9 & 9 & 9 & 16 \\
\hline & Execution cost [in thous. zl] & 35,50 & 27,31 & 29,74 & 19,42 & 19,42 & 43,69 & 49,32 \\
\hline \multicolumn{9}{|c|}{ Installations $(k=5)$} \\
\hline 1 & Execution time [working days] & 24 & 24 & 26 & 15 & 36 & 32 & 19 \\
\hline 1 & Execution cost [in thous. zl] & 46,00 & 46,00 & 49,83 & 28,75 & 69,00 & 61,33 & 36,42 \\
\hline 2 & Execution time [working days] & 22 & 29 & 34 & 13 & 42 & 34 & 21 \\
\hline & Execution cost [in thous. zl] & 50,18 & 38,07 & 38,11 & 33,17 & 59,14 & 57,73 & 32,95 \\
\hline 3 & Execution time [working days] & 29 & 27 & 24 & 17 & 28 & 37 & 16 \\
\hline & Execution cost [in thous. zl] & 38,07 & 40,89 & 53,99 & 25,37 & 88,71 & 53,05 & 43,24 \\
\hline
\end{tabular}


Table 1. Offers of the works execution in $n=7$ buildings for $m=9$ works submitted by subcontractors including the duration of the works and their cost - continued

\begin{tabular}{|c|c|c|c|c|c|c|c|c|}
\hline \multirow{2}{*}{\multicolumn{2}{|c|}{ CONTRACTORS (NUMBER/OFFER) }} & \multicolumn{7}{|c|}{ UNITS $j=$} \\
\hline & & 1 & 2 & 3 & 4 & 5 & 6 & 7 \\
\hline \multicolumn{9}{|c|}{ Windows and doors $(k=6)$} \\
\hline \multirow{2}{*}{1} & Execution time [working days] & 10 & 16 & 4 & 10 & 5 & 4 & 16 \\
\hline & Execution cost [in thous. zl] & 38,00 & 60,80 & 15,20 & 38,00 & 19,00 & 15,20 & 60,80 \\
\hline \multirow{2}{*}{2} & Execution time [working days] & 12 & 14 & 4 & 11 & 4 & 4 & 14 \\
\hline & Execution cost [in thous. zl] & 31,67 & 69,49 & 15,20 & 34,55 & 23,75 & 15,20 & 69,49 \\
\hline \multirow{2}{*}{3} & Execution time [working days] & 7 & 13 & 4 & 9 & 6 & 3 & 13 \\
\hline & Execution cost [in thous. $\mathrm{zl}$ ] & 54,29 & 74,83 & 15,20 & 42,22 & 15,83 & 20,27 & 74,83 \\
\hline \multicolumn{9}{|c|}{ Plastering, floors $(k=7)$} \\
\hline \multirow{2}{*}{1} & Execution time [working days] & 26 & 16 & 41 & 9 & 23 & 40 & 14 \\
\hline & Execution cost [in thous. zl] & 27,00 & 16,62 & 42,58 & 9,35 & 23,88 & 41,54 & 14,54 \\
\hline \multirow{2}{*}{2} & Execution time [working days] & 22 & 12 & 47 & 9 & 26 & 49 & 16 \\
\hline & Execution cost [in thous. zl] & 31,91 & 22,15 & 37,14 & 9,35 & 21,13 & 33,91 & 12,72 \\
\hline \multirow{2}{*}{3} & Execution time [working days] & 20 & 15 & 52 & 11 & 23 & 38 & 18 \\
\hline & Execution cost [in thous. zl] & 35,10 & 17,72 & 33,57 & 7,65 & 23,88 & 43,72 & 11,31 \\
\hline \multicolumn{9}{|c|}{ Fencing, driveways $(k=8)$} \\
\hline \multirow{2}{*}{1} & Execution time [working days] & 12 & 19 & 8 & 15 & 11 & 11 & 14 \\
\hline & Execution cost [in thous. zl] & 21,50 & 34,04 & 14,33 & 26,88 & 19,71 & 19,71 & 25,08 \\
\hline \multirow{2}{*}{2} & Execution time [working days] & 13 & 24 & 9 & 12 & 8 & 11 & 12 \\
\hline & Execution cost [in thous. zl] & 19,85 & 26,95 & 12,74 & 33,59 & 27,10 & 19,71 & 29,26 \\
\hline \multirow{2}{*}{3} & Execution time [working days] & 15 & 24 & 8 & 15 & 13 & 8 & 14 \\
\hline & Execution cost [in thous. $\mathrm{zl}$ ] & 17,20 & 26,95 & 14,33 & 26,88 & 16,68 & 27,10 & 25,08 \\
\hline \multicolumn{9}{|c|}{ Tiling, painting, sanitary whiteware $(k=9)$} \\
\hline \multirow{2}{*}{1} & Execution time [working days] & 18 & 15 & 16 & 23 & 26 & 17 & 27 \\
\hline & Execution cost [in thous. zl] & 41,50 & 34,58 & 36,89 & 53,03 & 59,94 & 39,19 & 62,25 \\
\hline \multirow{2}{*}{2} & Execution time [working days] & 15 & 18 & 13 & 27 & 26 & 16 & 28 \\
\hline & Execution cost [in thous. zl] & 49,80 & 28,82 & 45,40 & 45,17 & 59,94 & 41,64 & 60,03 \\
\hline \multirow{2}{*}{3} & Execution time [working days] & 23 & 12 & 12 & 27 & 22 & 13 & 25 \\
\hline & Execution cost [in thous. zl] & 32,48 & 43,23 & 49,19 & 45,17 & 70,84 & 51,25 & 67,23 \\
\hline
\end{tabular}

The number of possible solutions (schedules) in the illustrated example is: $7 ! * 3^{7 * 9}=5040 * 3^{63}=5,77 * 10^{33}$. The contractor has a deadline for the completion of the entire project amounting to 350 working days imposed by the investor. In connection with the established deadline the contractor will try to set a schedule for the execution of the works that minimizes the cost of used resources - among the contractors who submitted their bids. 
Table 2. Couplings between units $s^{F}$ occurring between the works $k$ and $k+1$ for $n=7$ units

\begin{tabular}{|c|c|c|c|c|c|c|c||}
\hline \multirow{2}{*}{ Works $\boldsymbol{k}=$} & \multicolumn{7}{|c||}{ Value $\boldsymbol{s}^{\boldsymbol{F}}$ [working days] } \\
\cline { 2 - 9 } & \multicolumn{7}{|c||}{ Units $=$} \\
\cline { 2 - 9 } & $\mathbf{1}$ & $\mathbf{2}$ & $\mathbf{3}$ & $\mathbf{4}$ & $\mathbf{5}$ & $\mathbf{6}$ & $\mathbf{7}$ \\
\hline $\mathbf{1}$ & 0 & 0 & 0 & 0 & 0 & 0 & 0 \\
\hline $\mathbf{2}$ & 5 & 5 & 5 & 5 & 5 & 5 & 5 \\
\hline $\mathbf{3}$ & 0 & 0 & 0 & 0 & 0 & 0 & 0 \\
\hline $\mathbf{4}$ & -5 & -5 & -5 & -5 & -5 & -6 & -5 \\
\hline $\mathbf{5}$ & -3 & -3 & -4 & -3 & -4 & -2 & -3 \\
\hline $\mathbf{6}$ & -1 & -1 & 0 & -1 & -2 & -2 & -1 \\
\hline $\mathbf{7}$ & 0 & 0 & 0 & 0 & 0 & 0 & 0 \\
\hline $\mathbf{8}$ & -11 & -11 & -9 & -13 & -13 & -10 & -16 \\
\hline
\end{tabular}

\section{METHOD FOR SOLVING OPTIMIZATION PROBLEM}

The described optimization problem shown in the above example, belongs to NP-hard discrete optimization problem. The difficulty in solving such a problem is caused by the fact that there are two different decision variables affecting the value of the objective function, which is the cost of the project. For searching the minimum cost of the project there is a proposed individual algorithm. This algorithm will use the approximate simulated annealing (SA) algorithm which belongs to the group of metaheuristics. The SA algorithm has been proposed in the work of Kirkpatrick [9]. This algorithm uses analogous to the thermodynamic process of cooling the solid in order to introduce the trajectory of the search of the local extremum. States of solid matter are seen analogously as individual solution to the problem, whereas the energy of the body as the value of the objective function. During the physical process of cooling the temperature is reduced slowly in order to maintain energy balance.

The SA algorithm starts with the initial solution, usually chosen at random. Then, in each iteration, according to established rules or randomly, there is the solution $\pi$ selected from the base neighbourhood $\pi$. It becomes the base solution in the next iteration, if the value of the objective function is better than the current base solution or if it otherwise may become the base solution with the probability of: $p=\exp \left(-\Delta / T_{i}\right)$, where $\Delta=c\left(\pi^{\prime}\right)-c(\pi), T_{i}$ - the temperature of the current iteration $i, c$ - the objective function. In each iteration there are $m$ draws from the neighbourhood of the current basic solution performed. 
The parameter called the temperature decreases in the same way as in the natural process of annealing. The most frequently adopted patterns of cooling are:

- geometrical $T_{i+1}=\lambda_{i} T_{i}$,

- logarithmic $T_{i+1}=T_{i} /\left(1+\lambda_{i} T_{i}\right)$,

where $i=0, \ldots, N-1, T_{0}$ - the initial temperature, $T_{N}$ - the final temperature, $N$ - number of iterations, $\lambda_{i}$ - parameter. In the algorithm there are usually parameter values $T_{0}, T_{N}, N$ adopted and parameter $\lambda_{i}$ is calculated. The relationship $T_{0}>T_{N}$ should take place, whereas $T_{N}$ should be small, close to zero. Below, a general method of SA algorithm used to solve the flow shop problem is presented:

Step 0. Determine the initial solution $\pi^{0} \in \Pi$. Substitute $\pi^{S A}=\pi^{0}, k=0, T=T_{0}$.

Step 1. Perform steps $1.1-1.3 x$-times.

Step 1.1. Substitute $k:=k+1$. Choose random $\pi \in N\left(V, \pi^{k-1}\right)$.

Step 1.2. If $c\left(\pi^{\prime}\right)<c\left(\pi^{S A}\right)$ then substitute $\pi S A=\pi^{\prime}$.

Step 1.3. If $c\left(\pi^{\prime}\right)<c\left(\pi^{k-1}\right)$ then substitute $\pi^{k}=\pi^{\prime}$. Otherwise, accept solution $\pi^{\prime}$ with a probability of $p=\exp \left(\left(c\left(\pi^{k-1}\right)-c\left(\pi^{\prime}\right)\right) / T\right.$, tj. $\pi^{k}=\pi^{\prime}$, if solution $\pi^{\prime}$ was not accepted.

Step 2. Change the temperature $\mathrm{T}$ according to a defined pattern of cooling.

Step 3. If $T>T_{N}$, return to step 1, otherwise STOP.

SA algorithms are used to solve many optimization problems, including flow shop problems considered in the context of discrete optimization problems [7, 13]. The SA algorithm was also used in solving optimization tasks in the scheduling of the construction projects (Time Coupling Methods - TCM) [5]. The results obtained using the SA algorithm are slightly worse than those obtained by using the tabu search algorithm and are better than those obtained using the genetic algorithm [5]. Due to the existence of two different decision variables for solving optimization task in the present model of multiunit project there is the solution of the optimization proposed using the following algorithm created by author of the paper:

Let $\pi \in \Pi$ be any permutation determined at random $\left(\pi^{*}\right.$ - the best solution found so far, at the beginning $\pi^{*}=\pi$ ), let $R$ be the set of numbers of ways to carry out the works found at random ( $R^{*}$ the best solution found so far, for the beginning $R^{*}=R$ ), $\hat{C}$ - limitation of the deadline imposed by the project investor, MaxIter the adopted maximum number of iterations of the algorithm.

Step 1. Find the solution for the optimization task using SA metaheuristics (permutation $\delta$ ) of the minimizing the duration of the project satisfying the condition $C_{\max }(\delta, R) \leq \hat{C}$ with $R$ adopted as a set of numbers of ways to carry out the works. 
Step 2. Find the solution to the optimization problem using SA metaheuristics (the set of $\rho$ numbers of ways to implement the works) to minimize the cost of the project with the aim of sequencing of units expressed by the permutation $\delta$ and limitation of the project duration to the value $\hat{C}: C_{\max }(\delta, \rho) \leq \hat{C}$.

Step 3. If $U(\delta, \rho) \leq U\left(\pi^{*}, R^{*}\right)$, then $\pi^{*}=\delta, R^{*}=\rho$. Adopt $R=\rho$.

Step 4. If the Completion_Condition is satisfied, then STOP else go to Step 1.

The above algorithm is designed to search the space of solutions contained in $n$ ! possible schedules solving, in the found permutation and the task of minimizing the cost of the entire project. As a result, its operation provides the minimum value of the cost of the project from the entire search trajectory taking into account the imposed limitation concerning the duration of the project. The algorithm terminates with the condition of completion, which relies on performing MaxIter of its iterations.

In step 2, the task of minimizing the duration of the project is being solved. The following assumptions concerning the form and the parameters of the SA algorithm included in the step 2 were adopted:

- neighborhood $N_{\pi}$ contains permutations generated from $\pi$ with the use of "insert" move,

- Boltzmann function of acceptance was adopted,

- geometric cooling scheme was adopted, i.e. $T_{i+1}=\lambda T_{i}$ and $T_{0}=60, \lambda=0.99$, the number of considered solutions at a set temperature $-0.5 n$,

- maximum number of iterations of the algorithm SA in Step 2 - $50 n$.

In step 3, the task to minimize the cost of projects with limited duration value is being solved. The following assumptions concerning the form and parameters of the SA algorithm included in the step 3 were adopted:

- neighborhood $N_{R}$ contains sets of numbers of ways for the works execution generated from $R$ by a move which relies on changing of the randomly selected number of ways of work implementation by the randomly selected value +1 or -1 ,

- Boltzmann function of acceptance was adopted,

- geometric cooling scheme was adopted, i.e. $T_{i+1}=\lambda T_{i}$ oraz $T_{0}=60, \lambda=0.99$, the number of solutions considered at a fixed temperature $-2 n$,

- maximum number of iterations of the SA algorithm SA in step 3 - 20000.

Due to the adopted limitation - the duration of the project - the sequence of solving problems was determined in the order as given in the above algorithm: in step 1, the task is solved to minimize the 
duration of the project and then in step 2, the task is solved to minimize the cost of the project. Such a sequence of solving optimization problems will move the algorithm in the area of feasible solutions which meet the adopted limitation. The implementation of the presented algorithm for the considered model was made in Mathematica system. The optimization problem in the presented calculation example is based on the search for a schedule that minimizes the cost of subcontractors used by reducing the execution time of the works up to 350 days. This object is achieved by means of software created for the completion of the algorithm (step 4) after 1000 iterations. The cost of the project for initial solution (first iteration) amounts to 1970,01 thousand PLN (duration of the project -347 days).

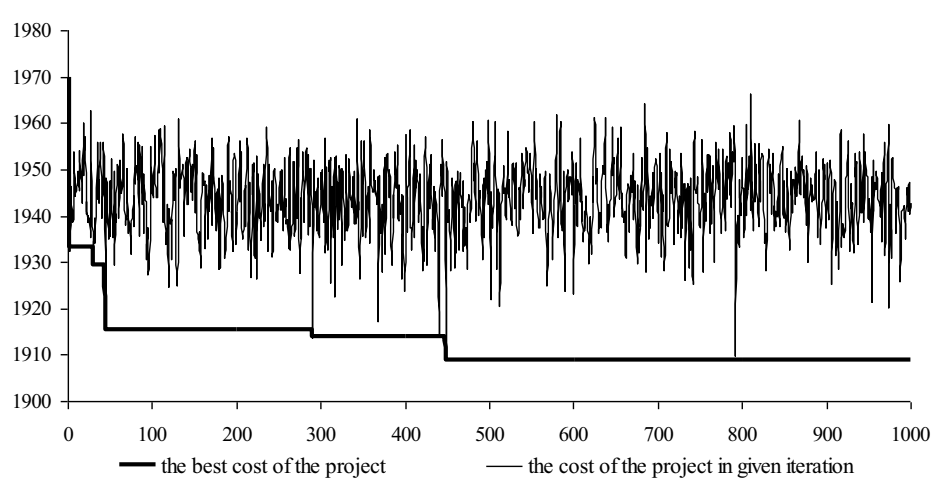

Fig. 2. The search trajectory for the optimal schedule in the calculation example

The lowest cost of the project was achieved in 448 iterations of the algorithm and it amounts to 1908.96 thousand PLN (duration of the project - 350 days) for the following decision variables:

$$
\begin{gathered}
\pi=(3,5,1,7,2,6,4) \text { and } \\
R=\left(R_{1}, R_{2}, R_{3}, R_{4}, R_{5}, R_{6}, R_{7}\right), \text { where: } \\
R_{1}=(1,1,1,1,3,1,1,3,3), R_{2}=(1,3,2,2,3,1,1,1,2), R_{3}=(1,2,2,3,2,2,3,1,1), R_{4}=(2,1,2,1,3,1,1,1,1), R_{5} \\
=(1,1,1,3,2,3,2,1,1), R_{6}=(1,2,2,2,2,3,1,1,1), \\
R_{7}=(1,1,3,3,1,1,2,1,1) .
\end{gathered}
$$

The cost of the project was improved by 3,1\% compared to the initial solution. Algorithm was coded in Mathematica system and executed on a PC with Intel Core i3-2100 processor. Computation time was about 30 hours. The long time of computation is caused by the inability of algorithm compilation in the Mathematica system. The increase in the number of iterations performed more than 1000 in algorithm did not result in lower cost of the project. The trajectory of exploration of the optimal schedule in the example is shown in Fig. 2. The algorithm can be used to 
search for the optimal solution for larger tasks than those presented in the example. The condition for the use of algorithm to solve them is to create a new software implementation coded, eg. in the $\mathrm{C}++$. It allows compiling commands and procedures, significantly accelerating the search for solutions optimization tasks.

\section{Conclusion}

Multiunit projects are special cases of construction projects, in which discrete optimization problems may occur. These problems are usually NP-hard due to the fact that they may be qualified as the permutation flow shop problems. Application of the additional parameter for works in the presented model - namely, the cost of works implementation enabled a significant increase in the number of possible solutions (schedules). The introduction of choices for the implementation of the selected works of the working group chosen from the team of three working groups revealed the existence of an additional decision variable, i.e. a set of numbers indicating the ways of works execution in all units of the project (apart from the sequencing of units). This resulted in the creation of the discrete optimization problem with two different decision variables - the cost criterion and constraint and the time of the project realization. To solve this problem an algorithm was created which searches the solution space, in which a metaheuristic simulated annealing algorithm was used. The results obtained using the SA algorithm are slightly worse than results obtained using the tabu search algorithm and are better than those obtained using the genetic algorithm [5]. The presented model of the multiunit project can be used when determining the optimal work schedule of subcontractors' works in construction companies using the flow organization system of work.

\section{REFERENCES}

1 K.P. Anagnostopoulos, L. Kotsikas, "Experimental evaluation of simulated annealing algorithms for the time-cost trade-off problem", Applied Mathematics and Computation, 217(1), 260-270, 2010.

2 W. Bożejko, Z. Hejducki; M. Uchroński, M. Wodecki, "Solving resource-constrained construction scheduling problems with overlaps by metaheuristic", Journal of Civil Engineering and Management 20(5), 649-659, 2014.

3 T. Hegazy, "Optimization of construction time-cost trade-off analysis using genetic algorithms", Canadian Journal of Civil Engineering, 26, 685-697, 1999.

4 T. Hegazy, A. Elhakeem, E. Elbeltagi, "Distributed Scheduling Model for Infrastructure Networks", Journal of Construction Engineering and Management, 130(2), 160-167, 2004.

5 Z. Hejducki, M. Podolski, "Scheduling of construction projects with application of metaheuristic algorithms" (in Polish). Journal of Science of the gen. Tadeusz Kosciuszko Military Academy of Land Forces, 44(4), pp 68-79, 2012, http://www.zeszyty-naukowe.wso.wroc.pl/fulltxt.php?ICID=1116069 .

6 Z. Hejducki, M. Rogalska, ,Time couplings methods”, Oficyna Wydawnicza PWr., Wrocław, 2011. 
7 H. Ishibuchi, S. Misaki, H. Tanaka, "Modified simulated annealing algorithms for the flow shop sequencing problem", European Journal of Operational Research, 81, 388-398, 1995.

8 K.M. Jaworski, "Design methodology of the construction" [in Polish], Wydawnictwo Naukowe PWN, Warszawa, 1999.

9 S. Kirkpatrick, C.D. Gelatt, M.P. Vecchi, “Optimization by simulated annealing”, Science, 220, 671-680, 1983.

10 H. Li, P. Love, "Using improved genetic algorithms to facilitate time-cost optimisation", Journal of Construction Engineering and Management, 123(3), 233-237, 1997.

11 R. Marcinkowski, "Resource allocation methods in engineering - construction activities" (in Polish), Warszawa, WAT, 2002.

12 J. Mrozowicz, "Methods of organization building processes taking into account time couplings" (in Polish), Dolnośląskie Wyd. Edukacyjne, Wrocław, 1997.

13 F.A. Ogbu, D.K. Smith, "The application of the simulated annealing algorithm to the solution of the n/m/Cmax flowshop problem", Computers \& Operations Research, 17(3), 243-253, 1990.

14 S. T. Ng, Y. Zhang, "Optimizing construction time and cost using ant colony optimization approach", Journal of Construction Engineering and Management, 134(9), 721-728, 2008.

15 M. Podolski, "Analysis of new applications of job scheduling theory in construction work organization" (in Polish), $\mathrm{PhD}$ thesis, Wrocław University of Technology, Wrocław, Poland, 2008, http://www.dbc.wroc.pl/Content/2515/Podolski_Analiza_PhD.pdf.

16 M. Podolski, "Scheduling of multiunit projects using tabu search algorithm". Journal of Science of the gen. Tadeusz Kosciuszko Military Academy of Land Forces, 47(1), pp 110-122, 2015, http://www.zeszytynaukowe.wso.wroc.pl/fulltxt.php?ICID $=1158558$.

17 M. Podolski, "Time/cost optimization in scheduling of multiunit construction projects" (in Polish), Przegląd Budowlany, nr 2, pp 48-53, 2015.

18 R. Sonmez, Ö. H. Bettemir, "A hybrid genetic algorithm for the discrete time-cost trade-off problem", Expert Systems with Applications 39, 11428-11434, 2012.

19 Y. Xiong, Y. Kuang, "Applying an ant colony optimization algorithm-based multiobjective approach for time-cost trade-off”, Journal of Construction Engineering and Management, 134(2), 153-156, 2008.

Received 04. 05. 2015

Revised 07. 07. 2015

\section{LIST OF FIGURES AND TABLES:}

Fig. 1. The graph for the described model of the project with the marked critical path

Rys. 1. Graf dla rozważanego modelu przedsięwzięcia z zaznaczoną ścieżką krytyczną.

Fig. 2. The search trajectory for the optimal schedule in the calculation example

Rys. 2. Trajektoria poszukiwań optymalnego harmonogramu w przykładzie obliczeniowym

Tab. 1. Offers of the works execution in $n=7$ buildings for $m=9$ works submitted by subcontractors including the duration of the works and their cost

Tab. 1. Oferty realizacji robót $\mathrm{w} n=7$ budynków mieszkalnych dla $m=9$ robót złożone przez podwykonawców zawierające czas trwania robót oraz ich koszt

Tab. 2. Couplings between units $s^{F}$ occurring between the works $k$ and $k+1$ for $n=7$ units

Tab. 2. Sprzężenia między obiektami $s^{F}$ występujące między robotami $k$ i $k+1$ dla $n=7$ budynków mieszkalnych 


\section{HARMONOGRAMOWANIE PRACY ZASOBÓW W PRZEDSIĘWZIĘCIU WIELOOBIEKTOWYM Z ZASTOSOWANIEM KRYTERIUM KOSZT / CZAS}

Slowa kluczowe: harmonogramowanie przedsięwzięć budowlanych, symulowane wyżarzanie, flow shop, optymalizacja, wybór wykonawców

\section{STRESZCZENIE:}

Ze względu na możliwości planowania przedsięwzięcia budowlane można podzielić na dwa podstawowe rodzaje: przedsięwzięcia typu „kompleks operacji” oraz takie, które mogą być zorganizowane zgodnie z zasadami metody pracy równomiernej, czyli w systemie pracy potokowej [3]. W systemach pracy potokowej najczęściej rozważanym kryterium optymalizacji harmonogramów przedsięwzięć realizowanych w tym systemie jest czas trwania całego przedsięwzięcia $[1,5,6]$. W referacie przedstawiony jest model systemu pracy potokowej, w którym są uwzględnione koszty realizacji robót w przedsięwzięciu, co będzie prowadzić do rozwiązywania zagadnienia optymalizacji dyskretnej z zależnością czas/koszt. Dla rozpatrywanego w referacie modelu zakłada się przyjęcie sytuacji deterministycznej. Zakłada się, że każdy rodzaj robót można wykonać na maksymalnie trzy sposoby przyjmując dla każdego sposobu czas trwania i koszt realizacji roboty. Zagadnienie wyboru zasobów sprowadza się do wyboru sposobu wykonania robót w przedsięwzięciu. W modelu przedsięwzięcia można wyróżnić problem optymalizacyjny, w którym można zawarte są dwie, oddzielne zmienne decyzyjne. Pierwsza z nich to kolejność realizacji obiektów (działek roboczych), która jest reprezentowana przez permutację o długości równej liczbie obiektów. Druga z nich to macierz numerów sposobów realizacji robót (od 1 do 3) o wymiarach równych liczbie robót i liczbie obiektów w przedsięwzięciu. Problem optymalizacyjny w modelu jest zadaniem optymalizacji jednokryterialnej, które będzie polegało na minimalizacji kosztu całego przedsięwzięcia przy założonym ograniczeniu dotyczącym terminu jego realizacji. Rozpatrywany model systemu pracy potokowej jest NP-trudnym zagadnieniem optymalizacyjnym i wykorzystuje założenia permutacyjnego problemu przepływowego z kryterium czasu wykonywania wszystkich zadań (problem FP ||$C_{\max }$ ), który jest rozważany w teorii szeregowania zadań. W związku z istnieniem dwóch różnych zmiennych decyzyjnych dla rozwiązania zadania optymalizacyjnego w przedstawionym modelu proponuje się opracowany przez autora referatu algorytm, który wykorzystuje metaheurystykę symulowanego wyżarzania [2,4]. Algorytm ten ma na celu przeszukanie przestrzeni rozwiązań zawartych w $n$ ! możliwych harmonogramów, rozwiązując dla znalezionej permutacji zadanie minimalizacji kosztu całego przedsięwzięcia. W referacie podano przykład obliczeniowy optymalizacji harmonogramu przedsięwzięcia budowlanego polegającego na realizacji grupy budynków mieszkalnych. Przedstawiony model przedsięwzięcia wieloobiektowego może znaleźć zastosowanie podczas ustalania optymalnego harmonogramu pracy podwykonawców firm budowlanych przy zastosowaniu potokowego systemu pracy.

\section{REFERENCES:}

1 W. Bożejko, Z. Hejducki; M. Uchroński, M. Wodecki, "Solving resource-constrained construction scheduling problems with overlaps by metaheuristic", Journal of Civil Engineering and Management 20(5), 649-659, 2014.

2 H. Ishibuchi, S. Misaki, H. Tanaka, "Modified simulated annealing algorithms for the flow shop sequencing problem", European Journal of Operational Research, 81, 388-398, 1995

3 K.M. Jaworski, „Metodologia projektowania realizacji budowy”, Wydawnictwo Naukowe PWN, Warszawa 1999.

4 S. Kirkpatrick, C.D. Gelatt, M.P. Vecchi, "Optimization by simulated annealing”, Science, 220, 671-680, 1983.

5 J. Mrozowicz, „Metody organizacji procesów budowlanych uwzględniające sprzężenia czasowe”, Dolnośląskie Wyd. Edukacyjne, Wrocław 1997.

6 M. Podolski, „Analiza nowych zastosowań teorii szeregowania zadań w organizacji robót budowlanych”, praca doktorska, Raporty Inst. Bud. PWroc. 2008, Ser. PRE nr 5/08, http://www.dbc.wroc.pl/Content/2515/Podolski_Analiza_PhD.pdf . 